\title{
IMPACT OF HERBICIDES ON CONSUMPTION CHARACTERS OF POTATO TUBERS
}

\author{
Marek Gugała', Krystyna Zarzecka', Ewa Krasnodębska', Anna Sikorska' \\ 1 Siedlce University of Natural Sciences and Humanities, Prusa St. 14, 08-110 Siedlce, Poland, e-mail: gugala@ \\ uph.edu.pl
}

Received: 2016.01.06

Accepted: 2016.03.04

Published: 2016.04.01

\begin{abstract}
The aim of the undertaken studies was to determine the effect of the herbicides used in the experiment on important features of the consumption values of three varieties of edible potato. Test results come from a field experiment conducted in 2007-2010. The experiment was established as two-factor in the split-plot system in three repetitions. Two factors were tested in the experiment: factor I - potato varieties: Satina, Tajfun, Cekin; factor II - five methods of weed control. Darkening of the pulp of cooked tubers after $10 \mathrm{~min}, 2$ and 24 hours shape the ways of weed control of the plantation and the genotype of the grown varieties. The use of herbicides in 2-5 variants has significantly increased the darkening of the pulp. The Tajfun variation darkened to the lowest degree, and Cekin to the largest degree.
\end{abstract}

Keywords: varieties, herbicides, pulp darkening, culinary type.

\section{INTRODUCTION}

The edible potato is a plant characterised by a strong reaction to the infestation, what is caused by the cultivation of a wide row spacing and slow initial growth [Urbanowicz 2010a].

Herbicides are a permanent element in the plant cultivation technology. Their use ensures high effectiveness of weed control, limits competitiveness of weeds compared to the crops, reduces workloads and facilitates field maintenance [Kucharski and Rola 2007].

Potato tubers for consumption and processing for food should have good morphological features, which, to a small extent, depend on the environment. The chemical composition of tubers undergoes much greater changes, which decide about the quality of the edible potato [Zgórska and Grudzińska 2012].

The edible potato in addition to such qualitative features as the dry matter content, starch content, should be characterised by high level of traits determining its usefulness, i.e., taste and darkening of raw and cooked tubers [Zarzecka and Gugała 2004].
The aim of the study was to determine the effect of herbicides used in the experiment on darkening of the pulp of the tubers of three varieties of the edible potato.

\section{MATERIALS AND METHODS}

Test results come from a field experiment conducted in 2007-2010 at the Agricultural Experimental Station Zawady belonging to the University of Natural Sciences and Humanities in Siedlce. The experiment was established as twofactor in the split-plot system in three repetitions.

The experiment studied two factors:

I. factor - varieties of the potato: Satina, Tajfun, Cekin.

II. factor - five methods of weed control:

- mechanical care - a control object,

- mechanical-chemical care, i.e., from sunrise ridging connected with harrowing, before sunrise herbicide Command $480 \mathrm{EC}$ $-0.2 \mathrm{dm}^{3} \cdot \mathrm{ha}^{-1}$,

- mechanical-chemical care, i.e. from sunrise ridging connected with harrowing, 
before sunrise spraying with a herbicide mixture of Command 480 EC $0.2 \mathrm{dm}^{3} \cdot \mathrm{ha}^{-1}$ + Disperse Afalon 450 S.C. $1.0 \mathrm{dm}^{3} \cdot \mathrm{ha}^{-1}$,

- mechanical-chemical care, i.e., from sunrise ridging connected with harrowing, before sunrise herbicide Stomp $3.5 \mathrm{dm}^{3} \cdot \mathrm{ha}^{-1}$,

- mechanical-chemical care, i.e. from sunrise ridging connected with harrowing, before sunrise spraying with a herbicide mixture of Stomp $3.5 \mathrm{dm}^{3} \cdot \mathrm{ha}^{-1}+$ Disperse Afalon 450 S.C. $1.0 \mathrm{dm}^{3} \cdot \mathrm{ha}^{-1}$.

Ratings of darkening of cooked tubers were performed on a longitudinal section after $10 \mathrm{~min}$ utes, 2 hours and 24 hours in the 1-9 scale according to the colour tables of the Danish scale, where 9 - means no darkening, and 1 - the strongest darkening [Roztropowicz et al. 1999].

The obtained test results were developed statistically using the variance analysis.

Weather conditions during the research were quite diverse (Table 1). According to the calculated hydrothermal ratio of Sielianinow, all tested growing seasons were characterised by the lack of drought, however, months with extreme conditions were alternating, from strong drought to the lack of drought. The highest number of rainfall was recorded in the growing season $2010-459.7$ $\mathrm{mm}$ and the average air temperature was $15.6{ }^{\circ} \mathrm{C}$ and it was higher by $0.6{ }^{\circ} \mathrm{C}$ compared to the longterm average. The lowest amount of rainfall $354.4 \mathrm{~mm}$ was noted in 2009 with the average air temperature of $15.1{ }^{\circ} \mathrm{C}$. The growing season 2008 was characterised by the rainfall at the level of
$371.4 \mathrm{~mm}$ and the air temperature did not deviate from the long-term norm and was $14.9^{\circ} \mathrm{C}$.

\section{RESULTS AND DISCUSSION}

Concluding from previous studies it was decided that the darkening of the pulp of cooked tubers be marked after $10 \mathrm{~min}$. after 2 hours and after 24 hours both by the variety properties, ways of weed control and weather conditions in various years of the study.

The greatest darkening of the pulp of the cooked tubers marked in all three observations dates (Table 2, 3, 4) characterised the Cekin variety - respectively 88.66 ; 8.49 and 8.39 degree, while the darkest one the Tajfun variety $8.82 ; 8.71$ and 8.65 degree. These results were confirmed in the studies of Ciećki et al. [2005], Urbanowicz [2010b] and of Zarzyńska and Goliszewski [2006] who stated that the darkening of the tubers pulp mainly depends on genetic features of individual varieties of the potato.

A factor exerting a significant impact on darkening of the pulp of cooked tubers marked after 10 minutes and after 2 and 24 hours included the ways of weed control. The darkest tubers were found in objects, on which a mixture of herbicides was used, i.e., 3. (mechanical-chemical care, to sunrise ridging connected with harrowing, and about 7 days before sunrise spraying with a herbicide mixture of Command $480 \mathrm{EC} 0.2 \mathrm{dm}^{3} \cdot \mathrm{ha}^{-1}$ + Disperse Afalon $450 \mathrm{SC} 1.0 \mathrm{dm}^{3} \mathrm{ha}^{-1}$ ) and 5 . (mechanical-chemical care, i.e., to sunrise ridg-

Table 1. Weather conditions during potato growth (2008-2010)

\begin{tabular}{|c|c|c|c|c|c|c|c|}
\hline \multirow{2}{*}{ Years } & \multicolumn{7}{|c|}{ Months } \\
\hline & IV & V & VI & VII & VIII & IX & IV-IX \\
\hline \multicolumn{7}{|c|}{ Rainfalls [mm] } & Sum \\
\hline 2008 & 28.2 & 85.6 & 49.0 & 69.8 & 75.4 & 63.4 & 371.4 \\
\hline 2009 & 8.1 & 68.9 & 145.2 & 26.4 & 80.9 & 24.9 & 354.4 \\
\hline 2010 & 10.7 & 93.2 & 62.6 & 77.0 & 106.3 & 109.9 & 459.7 \\
\hline Multiyear sum (1987-2000) & 38.6 & 44.1 & 52.4 & 49.8 & 43.0 & 47.3 & 275.2 \\
\hline \multicolumn{7}{|c|}{ Air temperature $\left[{ }^{\circ} \mathrm{C}\right]$} & Mean \\
\hline 2008 & 9.1 & 12.7 & 17.4 & 18.4 & 18.5 & 12.2 & 14.7 \\
\hline 2009 & 10.3 & 12.9 & 15.7 & 19.4 & 17.7 & 14.6 & 15.1 \\
\hline 2010 & 8.9 & 14.0 & 17.4 & 21.6 & 19.8 & 11.8 & 15.6 \\
\hline Multiyear mean (1987-2000) & 7.8 & 12.5 & 17.2 & 19.2 & 18.5 & 13.1 & 14.7 \\
\hline \multicolumn{7}{|c|}{ Sielianinow's hydrothermic coefficients* } & Mean \\
\hline 2008 & 1.04 & 2.18 & 0.94 & 1.25 & 1.36 & 1.73 & 1.39 \\
\hline 2009 & 0.26 & 1.72 & 3.08 & 0.44 & 1.48 & 0.57 & 1.28 \\
\hline 2010 & 0.40 & 2.14 & 1.20 & 1.15 & 1.74 & 3.10 & 1.61 \\
\hline
\end{tabular}

* Coefficient value: $<0.5$ - strong drought; 0.51-0.69 - mild; 0.70-0.99 - weak pure drought; $\geq 1$ - fault drought. 
Table 2. The cooked tubers darkening after 10 minutes, range 1-9

\begin{tabular}{|c|c|c|c|c|c|c|c|}
\hline \multirow{2}{*}{ Weed control methods } & \multicolumn{3}{|c|}{ Years } & \multicolumn{3}{|c|}{ Cultivars } & \multirow{2}{*}{ Mean } \\
\hline & 2008 & 2009 & 2010 & Cekin & Satina & Tajfun & \\
\hline 1.Control object & 9.00 & 8.83 & 8.88 & 8.87 & 8.96 & 8.89 & 8.90 \\
\hline 2.Command 480 EC $0.2 \mathrm{dm}^{3} \cdot \mathrm{ha}^{-1}$ & 8.96 & 8.79 & 8.64 & 8.71 & 8.83 & 8.85 & 8.80 \\
\hline $\begin{array}{l}\text { 3.Command } 0.2 \mathrm{dm}^{3} \cdot \mathrm{ha}^{-1}+\text { Disperse } \\
\text { Afalon } 1.0 \mathrm{dm}^{3} \cdot \mathrm{ha}^{-1}\end{array}$ & 8.92 & 8.71 & 8.35 & 8.52 & 8.70 & 8.76 & 8.66 \\
\hline 4.Stomp $400 \mathrm{SC} 3.5 \mathrm{dm}^{3} \cdot \mathrm{ha}^{-1}$ & 9.00 & 8.79 & 8.57 & 8.67 & 8.85 & 8.85 & 8.79 \\
\hline $\begin{array}{l}\text { 5.Stomp } 3.5 \mathrm{dm}^{3} \cdot \mathrm{ha}^{-1}+\text { Disperse } \\
\text { Afalon } 1.0 \mathrm{dm}^{3}\end{array}$ & 8.96 & 8.72 & 8.30 & 8.55 & 8.67 & 8.77 & 8.66 \\
\hline Mean & 8.97 & 8.77 & 8.55 & 8.66 & 8.80 & 8.82 & - \\
\hline $\begin{aligned} \mathrm{LSD}_{0.05} & \text { for: } \\
\text { - } & \text { years } \\
\text { - } & \text { cultivars } \\
\text { - } & \text { weed control methods }\end{aligned}$ & & & & & & & $\begin{array}{l}0.13 \\
0.13 \\
0.20\end{array}$ \\
\hline
\end{tabular}

Table 3. The cooked tubers darkening after 2 hours, range 1-9

\begin{tabular}{|c|c|c|c|c|c|c|c|}
\hline \multirow{2}{*}{ Weed control methods } & \multicolumn{3}{|c|}{ Years } & \multicolumn{3}{|c|}{ Cultivars } & \multirow{2}{*}{ Mean } \\
\hline & 2008 & 2009 & 2010 & Cekin & Satina & Tajfun & \\
\hline 1. Control object & 8.96 & 8.79 & 8.57 & 8.67 & 8.80 & 8.84 & 8.77 \\
\hline 2. Command 480 EC $0.2 \mathrm{dm}^{3} \cdot \mathrm{ha}^{-1}$ & 8.76 & 8.73 & 8.49 & 8.55 & 8.67 & 8.76 & 8.66 \\
\hline $\begin{array}{l}\text { 3. Command } 0.2 \mathrm{dm}^{3} \cdot \mathrm{ha}^{-1}+ \\
\text { Disperse Afalon } 1.0 \mathrm{dm}^{3}\end{array}$ & 8.59 & 8.70 & 8.23 & 8.39 & 8.50 & 8.63 & 8.51 \\
\hline 4. Stomp $400 \mathrm{SC} 3.5 \mathrm{dm}^{3} \cdot \mathrm{ha}^{-1}$ & 8.64 & 8.74 & 8.39 & 8.49 & 8.60 & 8.69 & 8.59 \\
\hline $\begin{array}{l}\text { 5. Stomp } 3.5 \mathrm{dm}^{3} \cdot \mathrm{ha}^{-1}+\text { Disperse } \\
\text { Afalon } 1.0 \mathrm{dm}^{3}\end{array}$ & 8.55 & 8.69 & 8.23 & 8.34 & 8.51 & 8.62 & 8.49 \\
\hline Mean & 8.70 & 8.73 & 8.38 & 8.49 & 8.62 & 8.71 & - \\
\hline $\begin{aligned} \mathrm{LSD}_{0.05} & \text { for: } \\
\text { - } & \text { years } \\
\text { - } & \text { culitvars } \\
\text { - } & \text { weed control methods }\end{aligned}$ & & & & & & & $\begin{array}{l}0.16 \\
0.16 \\
0.19\end{array}$ \\
\hline
\end{tabular}

Table 4. The cooked tubers darkening after 24 hours, range 1-9

\begin{tabular}{|c|c|c|c|c|c|c|c|}
\hline \multirow{2}{*}{ Weed control methods } & \multicolumn{3}{|c|}{ Years } & \multicolumn{3}{|c|}{ Cultivars } & \multirow{2}{*}{ Mean } \\
\hline & 2008 & 2009 & 2010 & Cekin & Satina & Tajfun & \\
\hline 1. Control object & 8.89 & 8.71 & 8.43 & 8.57 & 8.68 & 8.79 & 8.68 \\
\hline 2.Command 480 EC $0.2 \mathrm{dm}^{3} \cdot \mathrm{ha}^{-1}$ & 8.68 & 8.67 & 8.36 & 8.43 & 8.55 & 8.71 & 8.57 \\
\hline $\begin{array}{l}\text { 3.Command } 0.2 \mathrm{dm}^{3} \cdot \mathrm{ha}^{-1}+\text { Disperse } \\
\text { Afalon } 1.0 \mathrm{dm}^{3}\end{array}$ & 8.55 & 8.62 & 8.15 & 8.30 & 8.44 & 8.58 & 8.44 \\
\hline 4.Stomp $400 \mathrm{SC} 3.5 \mathrm{dm}^{3} \cdot \mathrm{ha}^{-1}$ & 8.58 & 8.66 & 8.29 & 8.41 & 8.50 & 8.61 & 8.51 \\
\hline $\begin{array}{l}\text { 5.Stomp } 3.5 \mathrm{dm}^{3} \cdot \mathrm{ha}^{-1}+\text { Disperse } \\
\text { Afalon } 1.0 \mathrm{dm}^{3}\end{array}$ & 8.48 & 8.63 & 8.12 & 8.23 & 8.44 & 8.56 & 8.41 \\
\hline Mean & 8.63 & 8.66 & 8.27 & 8.39 & 8.52 & 8.65 & - \\
\hline $\begin{aligned} \mathrm{LSD}_{0.05} & \text { for: } \\
\text {. } & \text { years } \\
\text { - } & \text { culitvars } \\
\text {. } & \text { weed control methods }\end{aligned}$ & & & & & & & $\begin{array}{l}0.13 \\
0.13 \\
0.21\end{array}$ \\
\hline
\end{tabular}

ing connected with harrowing, and about 7 days before sunrise spraying with a herbicide mixture of Stomp $3.5 \mathrm{dm}^{3} \mathrm{ha}^{-1}+$ Disperse Afalon $450 \mathrm{SC}$ $\left.1.0 \mathrm{dm}^{3} \cdot \mathrm{ha}^{-1}\right)$. On the other hand, the smallest darkening of the pulp marked after 10 . minutes - on average $8.90^{\circ}$ and after 4 . hours - on average $8.77^{\circ}$ and after 24 . hours - on average $8.68^{\circ}$ was noted on the control object maintained only with mechanical care. These results are consistent with the earlier studies of Zarzecka et al. [2006], who have shown a significant effect of herbicide mixtures on darkening of tubers pulp, while herbicide mixtures used together with the aide did not affect the pulp darkening. On the other hand, 
Homouz et al. [2005], comparing the conventional and ecological potato cultivation technology, did not state the negative effect of herbicides on the culinary features of tubers. Also Urbanowicz [2010b] found no significant impact of the use of metribuzin on pulp darkening, however, he observed a slight deterioration of the discussed feature compared to the control object.

Weather conditions during the growing season have also significantly modified the degree of darkening of the pulp of the cooked potato tubers (Table 2, 3, 4). The greatest darkening was observed in the growing season 2010, where in August and September the rainfall over $100 \mathrm{~mm}$ was observed. Darkening of the pulp marked after 10 minutes averaged to $8.55^{\circ}$, after 2 hours on average $8.38^{\circ}$ and after 24 . - on average 8.27 degrees. The smallest darkening of the pulp of the cooked tubers was observed in the dry and warm year of 2009 , what was proved in the studies by Homouz et al. [2005] and Kołodziejczyk [2013].

\section{CONCLUSIONS}

1. Varieties grown in the experiment have significantly decided about the value of the discussed feature. The Cekin variety proved to be the most darkening one, while Tajfun the least darkening one.

2. Herbicides and their mixtures used in the experiment had a significant impact on the darkening of the pulp of the cooked tubers. The most darkened were the tubers collected from objects, on which the herbicide mixture was used consisting of Command $480 \mathrm{EC}+$ Disperse Afalon $450 \mathrm{SC}$ and Stomp $400 \mathrm{SC}+$ Disperse Afalon 450 SC., while the smallest darkening of the pulp characterised the tubers collected from the control object.

3. Variable weather conditions in individual years of study had a significant impact on the discussed features.

\section{REFERENCES}

1. Ciećko Z., Rogozińska I., Żołnowski A.C., Wyszkowski M. 2005. The influence of potassium fertilization, at different $\mathrm{N}$ and $\mathrm{P}$ levels, on the culinary features of potato tubers. Biul. IHAR, 237/238, 151-159.

2. Hamouz K., Lachman J., Dvoř́k P., Pivec V. 2005. The effect of ecological growing on the potatoes yield and quality. Plant Soil Environ., 51(9), 397-402.

3. Kołodziejczyk M. 2013. Phenotypic variation of yielding, chemical composition and quality characteristics of medium-late and late cultivars of edible potato. Acta Agroph., 20(3), 411-422.

4. Kucharski M., Rola H. 2007. Rotation of plants and herbicides as resistanse limiting element. Prog. Plant Prot., 47 (3), 365-370.

5. Roztropowicz S., Czerko Z., Głuska A., Goliszewski W., Gruczek T., Lis B., Lutomirska B., Nowacki W., Rykaczewska K., Sowa-Niedziałkowska G., Szutkowska M., Wierzejska-Bujakowska A., Zarzyńska K., Zgórska K. 1999. The methodology of observation, measurement and sampling in agronomic experiments with potato. Wyd. IHAR, 1-50.

6. Urbanowicz J. 2010a. Influence of metribuzin applied post emergence on yield of selected potato cultivars. Prog. Plant Prot., 50(2), 837-841.

7. Urbanowicz J. 2010b. Phytotoxic reaction of five potato cultivars to metribuzin applied postemergence. Part II. The influence on selected quality featares of tubers. Biul. IHAR, 257/258, 197-205.

8. Zarzecka K., Gugała M. 2004. Influence of the weeding control methods potato on quality culinary tubers. Annales UMCS, Sec. E, 59(3), 1481-1488.

9. Zarzecka K., Gugała M., Mystkowska I. 2006. Affecting of herbicides and tillage systems on selected consumptive value characters of table potato tubers. Prog. in Plant Protection, 46(2), 288-290.

10. Zarzyńska K., Goliszewski W. 2006. Growing potatoes in the ecological system and integrated tuber yield and quality. Pam. Puł., 142, 617-626.

11. Zgórska K., Grudzińska M. 2012. Changes in selected quality parameters of potato tubers during storage. Acta Agrophys., 19(1), 203-214. 